\title{
IbM BAGI SANTRI DI KECAMATAN GUNUNGPATI KOTA SEMARANG UNTUK MENINGKATKAN MINAT BERWIRAUSAHA
}

\author{
Kardoyo, Muhsin, Fachrurrozie, Ahmad Nurkhin \\ Fakultas Ekonomi Universitas Negeri Semarang \\ kardoyo@mail.unnes.ac.id
}

\begin{abstract}
Entrepreneurship education has become a very important thing in the present, not least at Islamic boarding schools (pondok pesantren). The form of entrepreneurship education is also diverse. Establishment of minimarket, animal husbandry, plantation and other business units in Islamic boarding schools is a step taken in order to improve entrepreneurial skills. However, the understanding and competence of santri entrepreneurship in Islamic boarding schools still requires strengthening and mentoring from academics and professionals. The target of service is the PP As Salafy Al Asror students who are studying at MA Al Asror, especially the XI and XII classes. The method of carrying out service activities is counseling, practice and mentoring. Extension activities are given to provide a real picture of the intricacies of entrepreneurship. Then proceed with the practice of preparing a business plan and mentoring the preparation of a business plan. The service partner gave a good response to the community services team. The community services activities can be carried out twice with the basic concepts of entrepreneurship and the preparation of a business plan. Participants can participate in activities enthusiastically and are able to produce business ideas contained in business plan documents. The first material presented by lecturer from Faculty of Economics UNNES. Whereas the service team provided intensive assistance in the second stage of community service activities.
\end{abstract}

Key words: entrepreneurship education, Islamic boarding schools, business plan

\section{PENDAHULUAN}

Pendidikan kewirausahaan menjadi hal yang sangat penting di masa sekarang ini, tak terkecuali di pondok pesantren. Banyak berkembang pondok pesantren yang mengunggulkan program pesantren wirausaha. Yaitu dalam rangka mencetak santri bernilai tambah, santri yang mempunyai kemampuan bisnis atau berwirausaha. Bentuk pendidikan kewirausahaan pun beraneka ragam. Pendirian unit usaha minimarket, peternakan, perkebunanan dan lainnya di pondok pesantren merupakan langkah yang diambil dalam rangkat meningkatkan kemampuan berwirausaha. Namun demikian, kompetensi wirausaha pengasuh atau ustadz di pondok pesantren memerlukan penguatan dan pendampingan dari kalangan akademisi dan profesional. Sehingga pendidikan kewirausahaan dapat berjalan dengan lebih efektif. 
Pesantren merupakan salah satu lembaga pendidikan Islam tertua yang sudah menjadi bagian dalam masyarakat Indonesia. Keberadaan pesantren memiliki arti penting dalam membentuk kepribadian santri agar memiliki budi pekerti yang baik (Umam, 2016). Pendidikan Islam yang dilaksanakan di pesantren bertujuan mempersiapkan dan menumbuhkan anak didik atau individu manusia yang prosesnya berlangsung terus menerus sehingga menjadi manusia yang berguna bagi dirinya dan bagi umatnya, serta dapat memperoleh suatu kehidupan yang sempurna (Hoerniasih, 2017).

Pondok pesantren dapat mengelola pendidikan kewirausahaan seperti keterampilan pertanian modern, perkebunan, pertukangan, peternakan, perikanan, teknologi informasi dan lainnya, dalam menyiapkan kader alumni sebagai sumber daya insani yang kreatif dan inovatif dalam mengais rezeki setelah menamatkan pendidikannya di pondok pesantren (Umam, 2016). Kompetensi tambahan ini sangat diperlukan. Selain ilmu pengetahuan tentang Islam dan nantinya santri akan menyebarkannya, santri juga memerlukan kompetensi bertahan hidup untuk memenuhi kebutuhan hidup bagi dirinya dan keluarganya nanti.

Nurkhin, Kusumantoro, \& Kiswanto (2015) menyatakan bahwa pendidikan kewirausahaan harus dikenalkan sejak usia dini, termasuk pada tingkatan sekolah yang paling dasar. Pendidikan kewirausahaan terbukti mempengaruhi minat berwirausaha siswa (Farida \& Nurkhin, 2016) dan juga mahasiswa (Atmaja \& Margunani, 2016). Di samping faktor lainnya seperti pengetahuan kewirausahaan dan lingkungan keluarga (Anggraeni \& Harnanik, 2015) serta personal attitude, lingkungan sosial dan efikasi diri (Maulida \& Nurkhin, 2017). Dengan demikian pendidikan kewirausahaan sangat penting untuk dilakukan dalam bentuk formal maupun non formal.

Pesantren memiliki peluang penting dalam menyelesaikan permasalahan ekonomi masyarakat terutama dalam mengatasi masalah pengangguran yang selama ini menjadi polemik dalam masyarakat dengan memberikan pendidikan kewirausahaan kepada setiap santrinya. Para santri yang mengikuti pendidikan kewirausahaan kewirausahaan dibekali dengan pemahaman bagaimana 
melakukan suatu usaha, mulai dari perencanaan (planning), analisis kelayakan usaha, pelaksanaan riil (doing), pemberdayaan (empowering), pemberian fasilitasi (facilitating), serta evaluasi (evaluating) dalam setiap kegiatan pendampingan, pemberian pelatihan, motivasi dan semacamnya (Umam, 2016). Pondok pesantren telah banyak mengembangkan program kewirausahaan bagi para santrinya. Melalui pembelajaran nilai-nilai keagamaan, para santri dididik bekerja dan berusaha sesuai syariah islam. Dalam pendidikan Islam mengajarkan manusia harus memiliki keterampilan manajerial (Hoerniasih, 2017). Pondok pesantren sangat penting dalam menerapkan pendidikan kewirausahaan.

Banyak pondok pesantren yang telah berhasil menerapkan pendidikan kewirausahaan. Pondok Pesantren AnNafieciyah Kecamatan Geger Kabupaten Bangkalan yang menggunakan usaha tahu sebagai bekal wirausaha bagi para santrinya. Pesantren agribisnis al Ittifaq di Ciwidey Bandung telah berhasil menjadik pesantren penghasil aneka sayur mayur. Pesantren al Amin Prenduan Sumenep telah berhasil mengembangkan usaha bahari dengan produk berbagai aneka industri ikan laut. Pondok Pesantren Madinatun Najah Pebayuran Bekasi sebagai pesantren agribisnis. Pesantren Sidogiri Pasuruan telah berhasil melakukan pengembangan aneka usaha (Umam, 2016).

Nilai-nilai kewirausahaan yang diinternalisasikan di pondok pesantren Sidogiri adalah nilai kewirausahaan yang berbasis ibadah, dimana segala kegiatan ekonomi yang dilakukan diniatkan untuk beribadah kepada Allah SWT. Proses pendidikan kewirausahaan yang dilaksanakan dengan stategi santri dilatih untuk mengelola lembaga ekonomi yang ada di pondok pesantren di bawah pantauan dan bimbingan dari kiai dan pengurus (Chotimah, 2015). Model pendidikan kewirausahaan disusun berdasarkan karakteristik jiwa kewirausahaan santri. Pendidikan kewirausahaan ditujukan pada tiga aspek, yaitu karakter, konsep, dan keterampilan (Widodo, 2014). Model pendidikan kewirausahaan di pesantren yaitu Model Wirausaha Integratif (MWI) (Sujianto, 2016)

Pondok Pesantren As Salafy Al Asror merupakan pondok pesantren yang cukup tua di wilayah Gunungpati Kota Semarang. PP Al Asror menyelenggarakan pendidikan 
pesantren dan pendidikan formal lainnya. Berdasarkan wawancara dengan Kyai Almamnuhin Kholid, pengasuh PP Al Asror, santri PP Al Asror minat berwirausaha santri masih perlu diasah dan ditingkatkan. Dengan demikian santri akan memiliki kompetensi tambahan ketika ia memasuki dunia sesungguhnya di masyarakat. Pondok telah mempunyai unit usaha untuk membantu pendanaan operasional pondok. Pondok mempunyai cita-cita untuk meningkatkan kemampuan berwirausaha santri, termasuk masyarakat sekitar. Pondok memberikan perhatian lebih pada kemampuan berwirausaha agar setiap orang dapat lebih produktif.

Perkembangan yang sangat cepat di kecamatan Gunungpati Kota Semarang menjadi potensi yang sangat bagus bagi santri yang mempunyai kemampuan berwirausaha. Keberadaan kampus UNNES dengan jumlah mahasiswa yang semakin meningkat tiap tahunnya menjadi target produk yang menggiurkan. Kebutuhan mahasiswa sangat banyak dimulai makanan, pakaian, dan lainnya. Di samping itu, perumahan telah banyak berdiri di sekitar Gunungpati.
Kebutuhan masyarakat modern adalah pemenuhan dengan cepat. Di sinilah dibutuhkan entrepreneur yang handal dan mampu menangkap peluang yang ada. Bisnis makanana telah menjamur. Bisnis laundry juga sangat banyak.

Permasalahan yang menjadi kendala yang dialami PP Al Asror dan pondok pesantren lainnya adalah kurangnya pengasuh atau ustadz/guru yang mempunyai keterampilan berwirausaha. Hal ini wajar, karena sebagian besar merupakan lulusan pondok pesantren atau kampus Islam yang jarang mempunyai keterampilan berbisnis. Kendala lainnya adalah keterbatasan dalam sarana prasarana atau peralatan. Peralatan tersebut cukup banyak dan lumayan mahal. Pondok pesantren belum mampu memenuhi kebutuhan tersebut. Peningkatan keterampilan tersebut akan lebih komprehensif jika dibalut dengan konsep pendidikan kewirausahaan. Banyak pesantren yang telah berhasil.

\section{TUJUAN DAN MANFAAT}

\section{Tujuan}

Tujuan kegiatan IbM ini adalah:

a. Meningkatkan pengetahuan dan minat berwirausaha santri. 
b. Meningkatkan kompetensi santri dalam menjalankan sebuah bisnis.

c. Meningkatkan pengetahuan dan keterampilan menyusun business plan.

Manfaat

Hasil dari pelaksanana IbM ini diharapkan dapat bermanfaat:

a. Bagi Santri

Meningkatknya pengetahuan dan minat berwirausaha santri serta kompetensi santri dalam menyusun dokumen business plan.

b. Bagi pelaksana kegiatan

Melaksanakan kegiatan pengabdian dan memperoleh masukan dari santri dan pengelolan pondok pesantren serta terjalinnya hubungan kerjasama antara kampus dan pondok pesantren.

\section{METODE}

\section{Target Kegiatan}

Anggota khalayak sasaran yang dilibatkan dalam kegiatan IbM ini adalah santri dari pondok pesantren as salafy Al Asror yang sedang sekolah di MA Al Asror, khususnya kelas XI dan XII.

\section{Luaran Kegiatan}

Kegiatan IbM ini akan menghasilkan luaran kegiatan berupa: a. Dokumen business plan dari santri dalam berkreasi di bisnis.

b. Meningkatkan minat dan pengetahuan santri dalam berwirausaha.

\section{Metode Pelaksanaan}

Kegiatan pengabdian bagi santri ini dilakukan dalam bentuk kegiatan penyuluhan, praktik, dan pendampingan melalui penyampaian teori secara menarik dan menggunakan media interaktif serta contoh konkret. Kemudian dilanjutkan dengan praktik menyusun business plan. Secara ringkas alur pemecahan masalah dalam pengabdian ini dilakukan adalah sebagai berikut:

Kegiatan pengabdian ini direncanakan melalui beberapa tahapan, sebagai berikut:

1. Kegiatan awal dan persiapan

Kegiatan awal dan persiapan dilakukan oleh tim pengabdi dengan beberapa pengurus pondok pesantren dan pengasuh PP As Salafy Al Asror sebagai tempat pelaksanaan kegiatan untuk berkoordinasi awal pelaksanaan kegiatan. Hal yang dikoordinasikan diantaranya adalah tempat pelaksanaan kegiatan dan delegasi 
masing-masing pondok pesantren yang ada di Kecamatan Gunungpati.

2. Pelaksanaan Kegiatan

Tujuan dari kegiatan ini adalah meningkatkan pengetahuan dan minat berwirausaha santri. Kegiatan yang akan dilakukan oleh tim pengabdi adalah dengan sharing, diskusi, praktik, penyuluhan, pendampingan, dan coaching.

3. Evaluasi kegiatan

Tujuan dari kegiatan ini untuk diskusi dan evaluasi dari semua tahapan kegiatan yang telah dilakukan serta rencana kedepan kelanjutan dari kegiatan pengabdian ini.

Evaluasi kegiatan pengabdian akan dilakukan secara komprehensif dimulai saat perencanaan kegiatan. Setiap tahapan akan dievaluasi dengan cara yang berbeda. Keterlibatan mitra akan menjadi salah satu indikator keberhasilan pengabdian ini. Indikator keberhasilan pelaksanaan kegiatan pengabdian akan diukur dengan tingkat keterampilan dan pemahaman peserta, yaitu lebih dari $60 \%$ peserta memiliki pemahaman dan keterampilan dalam mengolah makanan halal dan membuat kue serta mampu menyusun rencana bisnis yang prospektif.
Partisipasi mitra dalam kegiatan ini diantaranya adalah sebagai peserta aktif dan penyedia tempat pelaksanaan kegiatan. Pondok pesantren menentukan santrinya untuk mengikuti kegiatan pengabdian. dan juga menyediakan tempat yang representatif dan mendukung pelaksanaan kegiatan. Di samping itu, mitra pengabdian dari profesional akan menjadi narasumber utama dalam praktik mengolah makanan atau membuat kue.

\section{Materi Kegiatan}

Materi dalam kegiatan IbM ini adalah sebagai berikut;

a. Pengetahuan Wirausaha; revolusi industri 4.0, kompetensi yang dibutuhkan di masa yang akan datang, realitas wirausaha muda di Indonesia

b. Penyusunan Dokumen Business Plan; mengapa diperlukan dokumen business plan, bagaimana menyusun business plan

\section{HASIL DAN PEMBAHASAN}

Persiapan Pelaksanaan Kegiatan

\section{Pengabdian}

Kegiatan pengabdian ini telah dilaksanakan dengan baik dan lancar. Hal ini dikarenakan tim pengabdian mampu merencanakan kegiatan dan 
dapat berkoordinasi dengan mitra pengabdian. Sasaran kegiatan pengabdian ini adalah santri dan pengasuh. Direncanakan akan melibatkan beberapa pondok pesantren yang ada di Kecamatan Gunungpati. Dikarenakan kendala pendanaan, maka kegiatan pengabdian hanya melibatkan santri dan pengasuh di PP As Salafy Al Asror yang berada di J1. Kauman No. 1, RT. 003 / 002, Patemon, Gunung Pati, Kota Semarang, Jawa Tengah, 50228. Tim Pengabdian telah menjalin kerjasama dan silaturahim dengan PP As Salafy Al Asror sejak tahun 2016 melalui kegiatan pengabdian dan lain sebagainya.

Mitra pengabdian adalah PP As Salafy Al Asror yang berada di bawah Yayasan Al Asror. Yayasan tersebut merupakan Lembaga sosial dan Pendidikan yang mempunyai beberapa unit pengabdian. Yayasan Al Asror memili Lembaga Pendidikan formal yaitu MTs Al Asror, MA Al Asror, dan SMK Al Asror. Yayasan juga mengelola beberapa pondok, diantaranya pondok pesantren putra putri dan pondok pesantren hifdzil quran. Di samping itu, Yayasan juga mengelola taman Pendidikan al quran (TPQ) yang melibatkan santri sebagai pengajar. Yayasan Al Asror diasuh oleh KH. Al Mamnuhin Khalid.

Tahapan perencanaan kegiatan pengabdian telah dilakukan dengan baik. Hal ini dilakukan agar kegiatan pengabdian dapat diselenggarakan sesuai dengan tujuan yang telah ditetapkan. Kegiatan perencanaan yang telah dilakukan adalah sebagai berikut;

a. Berkoordinasi dengan pengasuh PP As Salafy Al Asror, yaitu dengan KH Al Mamnuhin Khalid. Koordinasi awal dilakukan untuk memberitahukan kepada mitra pengabdian bahwa kegiatan pengabdian akan segera dilaksanakan. Tim pengabdian juga menyampaikan surat ijin pelaksanaan kegiatan pengabgian. Tim pengabdian menyampaikan beberap informasi, diantaranya bentuk pelaksanaan kegiatan pengabdian, sasaran atau peserta, narasumber, dan termasuk konsumsi dan administrasi lainnya.

b. Koordinasi kedua jelang pelaksanaan kegiatan pengabdian. Kegiatan ini juga dilaksanakan dengan bersilaturahim atau sowan ke $\mathrm{KH}$ Al Mamnuhin Khalid. Koordinasi ditujukan untuk memastikan kesiapan mitra 


$\begin{array}{llll}\text { pengabdian, meliputi tempat } & \text { Tempat } & \text { : Serambi Masjid } \\ \text { pelaksanaan kegiatan pengabdian } & \text { PP As Salafy Al Asror } & \\ \text { beserta perlengkapan yang } & \text { Peserta } & \text { : Siswa kelas XI } \\ \text { dibutuhkan. Di samping itu, tim } & \text { dan XII } & & \\ \text { pengabdian memastikan sasaran } & \text { Narasumber : } & \text { Ahmad } \\ \text { peserta. Pada koordinasi ini, } & \text { Nurkhin, S.Pd., M.Si. dan Tim } \\ \text { diperoleh informasi bahwa peserta } & \text { Pengabdian } & & \\ \text { kegiatan pengabdian adalah santri } & \text { Materi } & \text { Wirausaha untuk } \\ \text { PP As Salafy Al Asror yang sedang } & \text { Tantangan Global di } & \end{array}$
kelas 11 dan kelas 12 dengan jumlah 64 anak. Tema pengabdian yaitu kewirausahaan dianggap cocok untuk santri tersebut untuk memberikan pemahaman, pengetahuan, dan contoh aplikatif. Informasi lainnya adalah waktu pelaksanaan kegiatan pengabdian, yang akan dilaksanakan pada hari Selasa, 17 Juli 2018 di serambi masjid pondok. Hal ini agar pelaksanaan kegiatan lebih kondusif.

\section{Pelaksanaan Kegiatan Pengabdian}

Kegiatan pengabdian masyarakat dilaksanakan dua kali tahapan, dengan rincian sebagai berikut;

a. Kegiatan pengabdian tahap I Hari, Tanggal : Selasa, 17 Juli 2018
Era Revolusi

Industri 4.0

b. Kegiatan pengabdian tahap II Hari, Tanggal :

Tempat : Kelas XI MA

Al Asror

Peserta : Siswa Kelas XI

MA Al Asror

Narasumber : : Tim

Pengabdian kepada Masyarakat

Materi : $\quad$ Menyusun

Business Plan

Pengasuh PP As Salafy Al Asror memberikan sambutan pengantar sebelum tim pengabdian menyampaikan materi. KH Almamnuhin Khalid sangat gembira menyambut tim pengabdian FE UNNES yang akan memberikan ilmu kepada santrinya, terkhusus mengenai wirausaha. Materi ini sangat penting untuk diberikan kepada santri karena akan sangat dibutuhkan untuk 
memasuki di dunia kerja dan dunia bermasyarakat. Beliau berharap kegiatan ini dapat dilaksanakan secara rutin tiap tahun dan memberikan bekal nyata seperti meningkatkan keterampilan tertentu (memasak kue, sablon, dan lain-lain). Beliau juga menyampaikan terimakasih kepada UNNES, khususnya Fakultas Ekonomi yang telah berkenan menjalin silaturahim dengan pondok.

Kegiatan pengabdian telah dilaksanakan dalam dua tahap, dengan materi yang berbeda. Materi pertama disampaikan oleh narasumber, Ahmad Nurkhin, S.Pd., M.Si. yang merupakan dosen FE UNNES dengan bidang keahlian Pendidikan Kewirausahaan. Penyampaian yang kontekstual memberikan bekal dasar tentang bagaimana peluang berwirausaha di masa yang akan depan. Peserta diberikan materi tentang keahlian dasar yang diperlukan agar mampu bersaing di era revolusi industri 4.0. Salah satu keahlian dasar itu adalah kemampuan komunikasi. Komunikasi yang dimaksud adalah kemampuan untuk menyampaikan gagasan dan pendapat di depan umum. Di samping itu, keahlian berkomunikasi akan melahirkan peluang kemampuang lobbying dan kepemimpinan serta kerjasama. Keahlian ini sangat diperlukan agar seseorang dapat menangkap peluang dengan membangung networking dan mampu meyakinkan orang lain atas jasa atau barang yang dijual.

Kreativitas dan inovasi merupakan materi berikutnya yang disampaikan oleh narasumber. Berwirausaha sangat dekat dengan kreasi dan inovasi. Siswa diminta untuk berani mengeluarkan ide dan gagasan. Agar terbuka pandangannya, siswa diminta untuk terus belajar, membaca, dan membaca. Membaca dalam arti luas, yaitu membaca situai dan kondisi di lingkungan sekitar agar dapat menangkap peluang bisnis. Di samping itu, siswa dapat belajar dari video-video di youtube mengenai kiat sukses berwirausaha. Siswa dapat belajar dari perjuangan para pengusaha-pengusaha muda Indonesia yang berhasil meniti bisnis.

Pemateri kemudian menyampaikan keberhasilan anak muda dalam berwirausaha. Contoh paling dekat adalah mahasiswa UNNES yang sangat kreatif dalam mengembangkan jiwa kewirausahaannya. Mahasiswa UNNES tidak takut ataupun malu-malu dalam berwirauaha. Produk yang paling 
terkenal dalam 2 tahun terakhir adalah it's milk. Di samping itu, mahasiswa UNNES aktif dalam organisasi HIPMI PT untuk memperoleh dan mengakses informasi bisnis dan wirausaha, khususnya di kota Semarang.

Penyampaian materi dilakukan secara simultan denga sesi tanya jawab. Siswa diminta memberikan tanggapan atas beberapa pertanyaan pemateri. Siswa juga diberikan kesempatan untuk menyampaikan pertanyaan atau lainnya kepada pemateri dan tim pengabdian. Peserta antusias mengikuti paparan materi. Hal ini tampak pada respon yang diberikan peserta ketika pemateri menyampaikan beberapa pertanyaan. Siswa dengan malu-malu, kadang juga berani menjawab dengan karakteristik masing-masing siswa. Siswa cukup mampu menangkap inti materi yang disampaikan. Siswa juga cukup mampu menangkap kondisi terkini, khususnya perkembangan dunia wirausaha oleh anak muda yang sangat menggeliat di Indonesia.

Kegiatan pengabdian tahap kedua telah dilaksanakan pada hari Selasa, 31 Juli 2018 di kelas XI MA Al Asror. Tim pengabdi sengaja mengurangi jumlah peserta agar materi dapat diterima dengan baik dan tim pengabdi dapat melakukan kegiatan pendampingan secara intensif. Materi pada kegiatan pengabdian tahap II adalah penyusunan business plan. Tim pengabdian memberikan penjelasan bagaimana menyusun dokumen rencana bisnis dan kemudian peserta diminta untuk membuatnya secara berkelompok. Tim pengabdian memberikan pendampingan secara intensif dibantu guru pendamping. Setelah siswa selesai menyusun dokumen business plan secara sederhana, peserta diminta untuk mempresentasikan di depan kelas. Terdapat 6 kelompok dalam kegiatan pengabdian tahap II dengan masingmasing terdiri dari 5 anggota.

Ide cerdas dan kreatif tampak pada hasil dokumen bisnis yang disusun oleh peserta pengabdian. Keenam ide bisnis tersebut adalah (1) laundry sepatu sandal; hemat dan cepat; (2) kue berbahan singkong; renyah dan murah; (3) menjual tanpa punya barang; mari berbisnis online; (4) jus buah segar; (5) warung kopi khas Indonesia; dan (6) roti pisang coklat plus.

Tim pengabdian memberikan apresiasi atas ide bisnis yang telah dihasilkan peserta pengabdian. Tim pengabdian memberikan reward bagi 
ide terkreatif termasuk dalam paparan di depan kelas. Ide bisnis yang mendapatkan reward utama adalah roti pisang coklat plus. Peserta dapat menyampaikan peluang bisnis dengan baik. Kelompok lain juga mendapatkan souvenir menarik dari tim pengabdian.

Kegiatan evaluasi juga dilakukan oleh tim pengabdian setelah kegiatan pengabdian selesai dilaksanakan dalam dua tahap. Evaluasi mencakup respon peserta dalam mengikuti kegiatan pengabdian dan output kegiatan yaitu ide bisnis yang tertuang dalam dokumen business plan. Diakui bahwa ide kreatif lebih cenderung dihasilkan oleh anak-anak muda yang mampu berpikir out of the box dan mereka yang berani dan menyukai tantangan. Evaluasi mengenai respon peserta adalah cukup baik. Hal ini tampak pada antusiasme peserta dalam mengikuti kegiatan pengabdian pada tahap I dan tahap II. Sehingga kegiatan pengabdian dapat berjalan dengan baik dan lancar. Evaluasi output adalah tersusunnya dokumen business plan yang cukup menarik sejumlah 6 dokumen.

\section{SIMPULAN DAN SARAN}

\section{Simpulan}

Simpulan dari uraian hasil pengabdian kepada masyarakat ini adalah sebagai berikut;

a. Kegiatan pengabdian masyarakat dengan topik pengembangan kewirausahaan santri dapat berjalan dengan baik dan lancar, walaupun terdapat pengurangan sasaran peserta. Sasaran pengabdian hanya santri PP As Salafy Al Asror yang sedang sekolah di MA Al Asror, khususnya kelas XI dan XII. Mitra pengabdian juga memberikan sambutan yang baik terhadap tim pengabdian dan dapat berkoordinasi dengan baik pula. Mitra kerjasama menyiapkan tempat pelaksanaan dan peserta kegiatan.

b. Kegiatan pengabdian dapat terlaksana sebanyak dua kali dengan materi konsep dasar berwirausaha dan penyusunan business plan. Peserta dapat mengikuti kegiatan secara antusias dan mampu menghasilkan ide bisnis yang tertuang dalam dokumen business plan. Materi pertama menghadirkan narasumber dari FE UNNES. Sedangkan tim pengabdi memberikan pendampingan secara 
intensif pada kegiatan pengabdian tahap kedua.

\section{Saran}

Saran yang dapat diberikan berdasarkan hasil pelaksanaan kegiatan pengabdian adalah tim pengabdi dapat menambah bentuk kegiatan agar mampu meningkatkan keterampilan sasaran pengabdian. Keterampilan yang dimaksud diantaranya keterampilan mengolah kue atau makanan ringan karena peluang bisnis di bidang tersebut cukup terbuka dan akan mampu dilakukan oleh santri atau siswa. Saran lainnya adalah tim pengabdi dapat menghadirkan pengusaha muda untuk meningkatkan semangat dan antusiasme peserta dalam mengembangkan ide bisnisnya.

\section{REFERENSI}

Anggraeni, B., \& Harnanik. (2015).

Pengaruh

Pengetahuan

Kewirausahaan Dan Lingkungan

Keluarga Terhadap Minat

Berwirausaha Siswa Kelas Xi Smk

Islam Nusantara Comal Kabupaten

Pemalang. Dinamika Pendidikan, $X(1), 42-52$.

Atmaja, A. tri, \& Margunani. (2016).

Pengaruh Pendidikan

Kewirausahaan Dan Aktivitas
Wirausaha Terhadap Minat

Berwirausaha

Mahasiswa

Universitas Negeri Semarang.

Economic Education Analysis

Journal, 3(2), 299-306.

Chotimah, C. (2015). Pendidikan kewirausahaan di pondok pesantren sidogiri pasuruan. Inferensi, Jurnal Penelitian Sosial Keagamaan, 8(1), 114-136.

Farida, S., \& Nurkhin, A. (2016). Pengaruh Pendidikan

Kewirausahaan, Lingkungan

Keluarga, Dan Self Efficacy Terhadap Minat Berwirausaha Siswa Smk Program Keahlian Akuntansi. Economic Education Analysis Journal, 5(1), 346-362.

Hoerniasih, N. (2017). Penerapan Nilainilai Agama Islam dalam Mengembangkan Pendidikan Kewirausahaan di Pondok Pesantren. In Seminar Nasional Pendidikan Nonformal FKIP Universitas Bengkulu (Vol. 1, pp. 94-106).

Maulida, W. N., \& Nurkhin, A. (2017). Pengaruh Personal Attitude Dan Lingkungan Sosial Terhadap Intensi Berwirausaha Dengan Efikasi Diri Sebagai Variabel Intervening Siswa Kelas Xi 
Kompetensi Keahlian Akuntansi

Smk Gajah Mada 01 Margoyoso

Pati Tahun Ajaran 2015/2016.

Economic Education Analysis

Journal, 6(2), 501-516.

Nurkhin, A., Kusumantoro, \&

Kiswanto. (2015). Model

Pendidikan Kewirausahaan di SMP

Alam Ar Ridho. In Seminar

Nasional "Entrepreneurship dan

Profesionalitas Guru di Era MEA"

(pp. 247-261). Wates: FE UNY

Yogyakarta.

Sujianto, A. E. (2016). Model

Pendidikan Wirausaha di
Pesantren. In The International

Conference on University-

Community Engagement (pp. 2-5).

Surabaya.

Umam, K. (2016). Pendidikan Kewirausahaan di Pesantren sebagai Upaya dalam Membangun Semangan para Santri untuk Berwirausaha. EKSYAR: Jurnal Ekonomi Syari'ah, 3(1), 47-64.

Widodo, S. (2014). Model pendidikan kewirausahaan bagi santri untuk mengatasi pengangguran di pedesaan. Mimbar, 31(2), 171179. 